\title{
THE RECLAMATION AND AGRARIAN RECONSTRUCTION OF WALCHEREN
}

\author{
E. DENIG \\ Government Service for Land and Water Use
}

SUMMARY

The reconstruction of Walcheren, which was devastated by the war in 1944, was carried out under the 1947 Land Reallocation Act. Thanks to this law it was not only possible to undertake extensive measures of land development such as land forming and renewal of the road and watercourse systems, but there was also an opportunity to enlarge smallholdings owing to the voluntary migration of a number of farmers to the North-East Polder. The construction of farmsteads, connections to piped water and electricity mains and extensive planting of trees and bushes all helped to give Walcheren its new look. After the reallocation works had legally terminated by the end of 1957 the actual reconstruction was also completed during the course of 1959. A land consolidation scheme of 17,350 hectares, the largest in the Netherlands to date, was thus brought to a conclusion.

\section{ThE ORIGIN OF THE ISLAND}

Like the other Zealand islands, the island of Walcheren was built up by the sea. The top stratum was formed during the holocene when fine-sandy to clayey material was deposited in the shallow inland sea shut off by a bank of the North Sea. Even before the Christian era a fen landscape began to develop behind the embankment which had meanwhile been blown up into dunes. Then came the struggle between the sea and land which has determined the main outline of the island.

$\mathrm{Up}$ to the year 1000 the protecting line of dunes was constantly broken by the force of the sea, causing numerous channels in the fen landscape. When the sea grew calm, sandy and sandy clay material was deposited in these creeks. The remaining peat was covered over by a layer of silt about 1 metre thick. After the silt had been deposited the peat sank and all soils with peat in the subsoil began to fall. Since there was no peat in the sanded-up creeks an inversion was formed in the relief. The originally low creek soils appeared on the landscape as ridges of constantly increasing height with the sinking of the so-called swamp soils, peat soils which were overlain by clay deficient in chalk. The differences in height amounted to 2 to 3 metres.

After the entire island was surrounded by dykes in the 11th and 12th centuries the low elevation of the swamp soils was increased still further by the excavation of the peat. This peat was burnt and table salt obtained from the ashes. What remained after the peat digging was a field of hummocks and depressions. In this manner an irregular landscape with ridges and low, hummocky plains was formed in the nucleus of the island some 15,000 hectares in area. Only the polder lands reclaimed since 1600 are fairly level.

\section{The PRE-War agrarian Structure}

The natural character of the land, as described above, has always determined

1) Received for publication November 29, 1959. 
the land use of Walcheren. The swampy soils, difficult to cultivate, uneven and insufficiently drained, were the traditional grasslands. These areas were badly accessible and unpopulated. On the other hand, the higher creek ridges which varied in width from some tens of metres to a kilometre, made excellent arable land. It was here that the population settled and the roads were constructed over the tortuous ridges. Arable land could also be found on the recent polder lands.

At the beginning of the war the island, some 20,000 hectares in area, had 70,000 inhabitants of which 41,000 lived in the towns of Middelburg and Flushing. Of the rest of the population, $90 \%$ found a direct or indirect living in agriculture. Of the land available for cultivation, $55 \%$ was in use as arable or horticultural land and the remainder as grassland.

A typical feature was the occurrence of small, fragmented holdings. The farmers' great attachment to the land had promoted the constant subdivision of holdings. This may be illustrated by a few figures. Of the 1,800 farms larger than 1 hectare, $55 \%$ had $1-5$ hectares, $16 \% 5-10$ hectares, $19 \% 10-20$ hectares, and only $10 \%$ more than 20 hectares.

When it is also borne in mind that owing to the differences of elevation water management has always been a difficult task, it will be obvious that the agrarian structure on the island of Walcheren left a good deal to be desired. Consequently the situation inherited from the past was felt by many to be unsatisfactory and the opportunity to start an entirely new line of development was eagerly accepted.

\section{The FlOOding AND ITS CONSEQUENCES}

During the autumn of 1944, when Antwerp fell to the Allies, Walcheren suffered the consequences of its key position by the Scheldt. This route to Antwerp had to be liberated at short notice, and the only way of ousting the Germans from the island they had converted into a fortress was' to flood the whole of it. The dykes were bombed and very soon $80 \%$ of the island was under water. The Germans capitulated and the war was over as far as Walcheren was concerned.

But the island had suffered grievous damage. The sea flowed freely in and out of four breaches in the dykes the width of which varied from 375 to 1,000 metres and the depth from 12 to 27 metres. As a result of the formation of creeks, the scouring by tidal currents and the covering by sand, there were severe losses of cultivable land.

For a whole year the water reigned supreme on Walcheren. Generous supplies of allied war materials enabled the first three breaches to be closed as early as October 1945. The last breach followed in February 1946 and it was possible to start pumping out the water. Not until after the land had been reclaimed was it possible to obtain a good view of the consequences of the disaster. Over 500 farmsteads and buildings had been demolished, the roads had been washed away or sunk, the watercourses were silted up, the rich vegetation was dead, and the soil ruined for years to come. In addition a number of fields were lost owing to the formation of creeks.

The first stage of recovery was taken in hand at once. The principal drainage canals were again opened. Much attention was paid to the restoration of the soil. The salt content would greatly decline after several years of flushing 
out, but the remaining structureless sodium clay could only be converted into a soil with a normal ion content by means of a forced dressing of calcium sulphate. The only areas in which a dressing of marl was sufficient were the former grasslands with their large store of humus. At first the former arable area was partly seeded to lucerne. When this crop is planted the soil does not require tilling for some years and this benefits the texture.

\section{The passing of the Land Recallocation Act}

When the ancient system of roads and watercourses had disappeared, together with the trees and bushes which used to mark the boundaries of the fields, there was an opportunity of giving the island an entirely new structure. The Government therefore decided to create a new situation on Walcheren. The draft Land Reallocation Act providing for this was presented to Parliament and was passed on 27th November 1947.

In addition to the facilities afforded by the old Land Consolidation Act 2) for re-allotment, construction of roads and watercourses, soil improvement and the like, the Land Reallocation Act provided also for the enlargement of smallholdings. Walcheren land users could lease a farm on the newly reclaimed North-East Polder, after which the land they had left behind could be used for enlarging smallholdings whose existence was hardly justified from social and economic considerations.

Hence it may be said that there were four motives behind the reallocation project. The former situation was far from ideal, so that a new parcelling and the accompanying land development works would have a beneficial effect. Reallocation would permit better compensation of the land losses from the spatial point of view. The sums required for the reconstruction of the island could be simultaneously expended on conprehensive improvement under a reallocation scheme. And finally, reallocation meant an opportunity to enlarge undersized holdings.

It is laid down in the law that the deposit of each farmer in the reallocation scheme is based on the assessed value of the lands before the disaster. After the operations have been completed the lands are reassessed and then allocated in proportion to the deposit. The law also provides that each parcel of land shall have access to a public road and shall be properly drained. Finally, the law also includes a provision regulating any migration to the North-East Polder. Under this provision anyone accepting a new farm in this area is obliged to cede to the Reallocation Committee his right to use land on Walcheren. This Committee which is responsible for the operations and is made up of representatives of the State and parties concerned, uses the land thus obtained in order to enlarge undersized holdings.

\section{THE RESEARCH}

At the very commencement of the operations a need was felt for organised scientific research. This meant at first the agricultural interpretation of the

2) Since 1954 there is a new Act oftering about the same possibilities as the Land Reallocation Act. 
soil map which had been compiled. A Scientific Department was therefore established as a part of the Reallocation Committee, its task being to keep in close touch with the Operational Bureau which had also been set up by the Committee.

The most important problems included in the programme related to the productivity of the soil, the water management, and the land forming. An investigation was made into the productivity and the need of tile drainage of a number of soil types, as well as the most desirable groundwater levels. The investigation also showed that good possibilities existed for converting grassland into arable, especially on the low, swampy soils. Lowering of the water table and levelling the land are the chief means of bringing about such a conversion. A study was also made a of the related problem of how to deal with the soil when levelling land and filling ditches.

After some years a fairly good grasp was obtained of the various problems. Thanks to the close link with the Operational Bureau it was possible for the results of research to be rapidly reduced to practice. The drainage advisory work was also very important for the reconstruction of the whole island. According to the advice given, the distance apart of drains should vary from 8 tot 40 metres. These distances differ considerably from the previous situation in which a distance of 15 metres was observed at the few places in which tile drainage existed.

\section{The project}

Some idea of the scope of the 17,350-hectare land consolidation scheme will be given below.

\section{a Accessibility}

A total of 8 kilometres of secondary roads, 64 kilometres of tertiary roads and 300 kilometres of rural roads were constructed. The new road system also includes 34 concrete bridges. All roads have metalled surfaces and a crown width of at least 7 metres. This obviates the difficulties which might arise
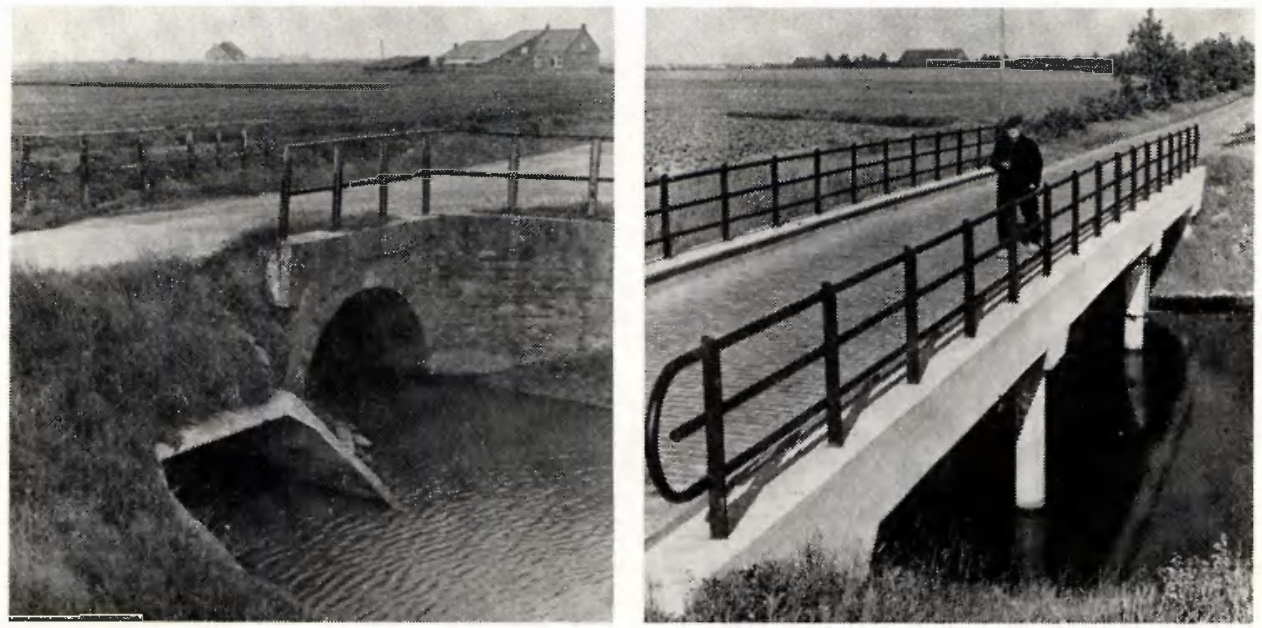

Fig. la and $1 \mathrm{~b}$ Reconstructing BRIDGes aNd RoAds. 
from laying cables, pipes, etc. too close to the metalling. The rural roads now have a metalling of not less than 3 metres, either of clinker or as a compact road surface.

In planning the new roads a field depth of about 350 metres was aimed at. If this is compared with the 800-metre depth which is usual in the North-East Polder it will be seen at once that Walcheren has a much denser road system. On the one hand this is due to the small average farm-size, and on the other to the wide divergencies in soil qualities which in many cases made it necessary to allocate more than one parcel of land. When it is realized that in the former state there were 460 kilometres of rural roads of which only 195 kilometres were metalled, the great progress made becomes immediately apparent. As a result of the improved road system and better parcelling the total length of rural roads has been reduced by $35 \%$, and all fields have now access to the public road.

\section{b Water management}

Owing to the great differences in elevation the island had to be divided into into a number of separate districts each of which had its own polder water level. Hence the polder water level now varies from 0.05 to 2.05 metres below mean sea level. As was formerly the case, the higher border districts discharge their water via the outlet sluices of Flushing and Veere. The capacity of the latter was enlarged. In addition it is now also possible to drain these border districts via the Boreel pumping station near Middelburg. After a third pump had been installed in this station the capacity of the latter was doubled. It will be clear that this improvement chiefly benefits the low-lying central area which is solely dependent on drainage pumps. Wherever possible the watercourse system was constructed with the use of the former waterways which were widened and deepened for the purpose. A total of 224 kilometres of small watercourses and 56 kilometres of large waterways were excavated. Although this meant that the length of watercourses was only increased from 240 to 280 kilometres, the discharge capacity has been more than doubled.
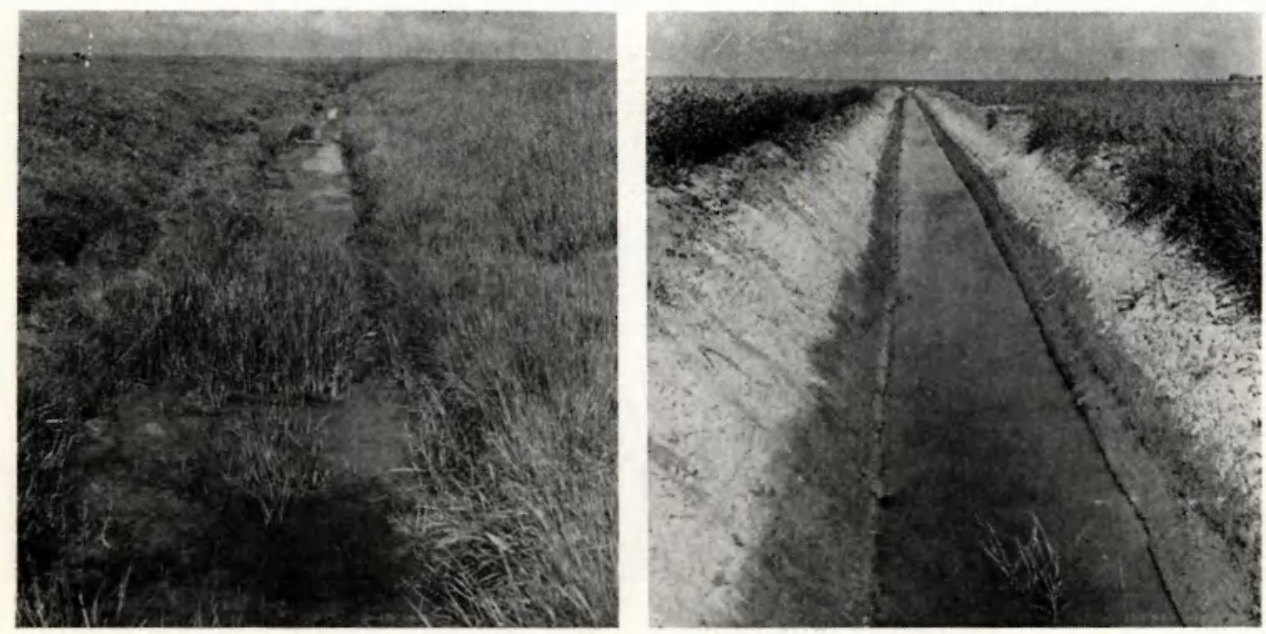

Fig. 2a and $2 b$ Inefficient and Filthy Watercounses are a thing of the Past. 
The carefully elaborated polder water level plan, which sometimes necessitated supplementary drainage or damming, also called for the construction of three small pumping plants and seven large and 57 small dams.

By all these various means a situation has been created in which the required polder water level can be nearly always maintained and salinization substantially prevented.

\section{c Land forming}

This work originally comprised the recultivation of fields which owing to the flooding had been covered with sand. Later on the land forming was solely directed to the formation of new, large parcels of land within the network of roads and watercourses. To ensure the proper management of these fields many unnecessary ditches had to be filled in, old roads abolished, elevations lowered and depressions raised. In all 2,500 kilometres of ditches were filled in and 1,200 kilometres excavated. Some 25 million cubic metres of earth were shifted. The filling-in of ditches and formation of larger parcels meant that direct drainage into the field ditches would usually be inadequate so that, in accordance with drainage advices, practically all arable fields and some pastures were tile drained.

Levelling work was at first confined to that connected with the filling-in and excavation of ditches; otherwise only the most urgent levelling work was executed. But subsequently a need was felt for levelling work on a larger scale in connection with the conversion to arable fields of the former uneven pastures. The population was first very sceptical about this work as it was feared that the soil would be destroyed for good. But two years after a number of experimental fields had been laid out the farmers became convinced of the utility of the work. Generally speaking two factors were important for obtaining a good profile structure, the replacement of the topsoil and the breaking up of hardpans.
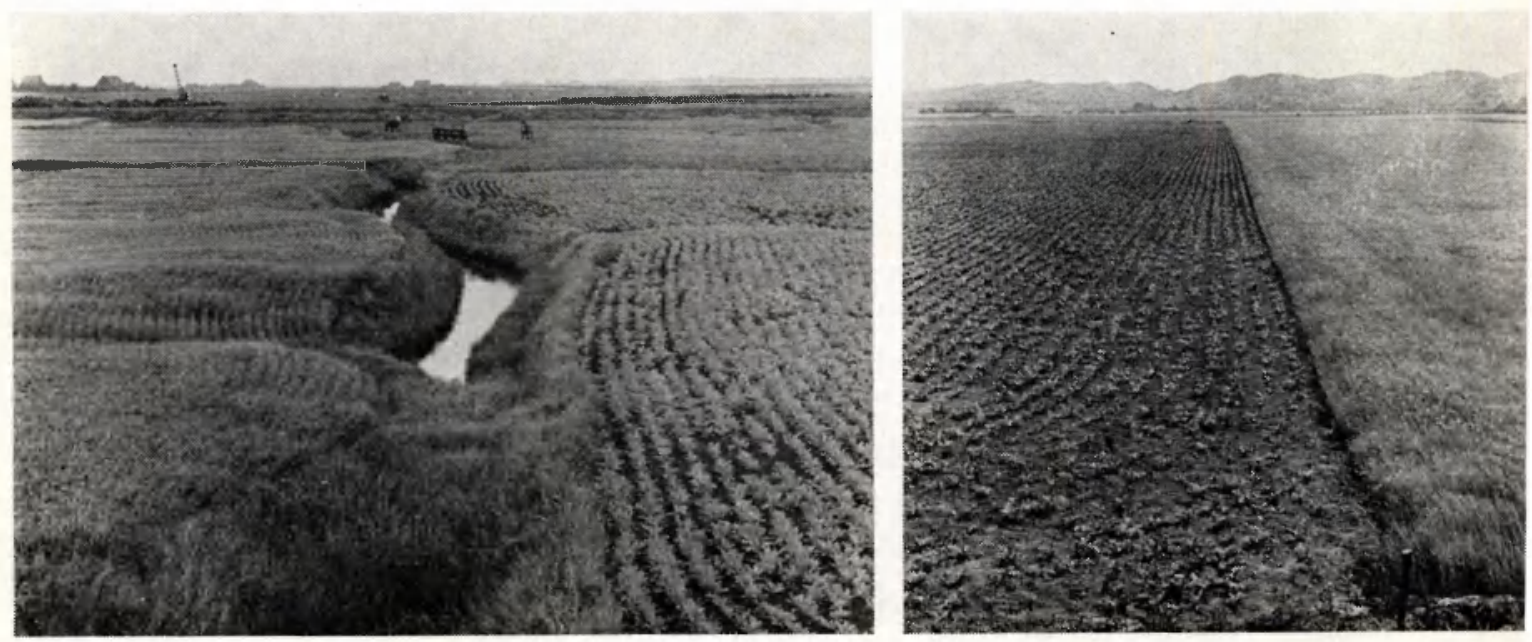

Fig. 3a and $3 \mathrm{~b}$ The former parcelling has been replaced by a logical pattern of RECTANGULAR FIELDS. 


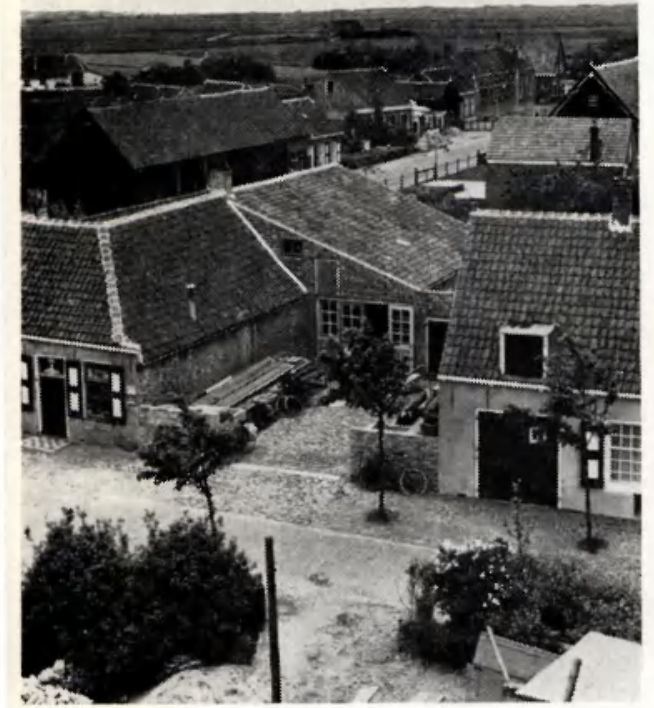

Fig. 4a AND $4 \mathrm{~b}$ FormerLy MANY FaRMS WERE CLUSTERED TOGETHER IN THE VILLAGES; THEY ARE NOW SPREAD OVER THE LAND.

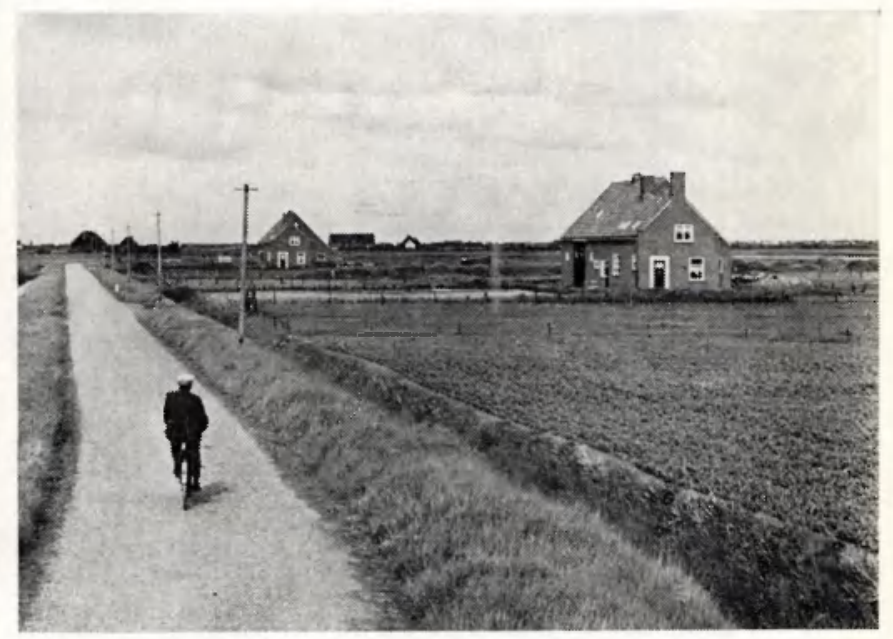

\section{$\mathrm{d}$ Farmsteads and provision of utilities}

It was found that 180 farmsteads would have to be rebuilt after the flooding. They were not always rebuilt on their old site; many farmsteads which used to be near or in the villages ware re-sited in the middle of the land belonging to them. 17 farmsteads were built on land which owing to defective drainage and lack of access was formerly considered an inferior farming district. Since farmers settled here from districts in which the land was most needed for the enlargement of undersized holdings, the establishment of these farms helped to promote the success of the farm enlargement projects.

Even before the war the supply of drinking water for livestock was a very difficult matter, as in many cases the only available water was rainwater or brackish ditchwater. By digging shallow wells and damming up ditches an attempt was made to reduce the costly and time-consuming work of conveying drinking water to the meadows. Such an inadequate water supply obviously had a bad effect on farming results, so that it is scarcely surprising that after the flooding a priority plan was worked out for supplying drinking water: this was put into effect during subsequent years. In all nearly 700 meadows, houses and farm buildings were connected to the water main. It was also found possible to connect more than 300 remote buildings to the electricity system.

\section{e Landscaping}

Before the war the island of Walcheren was justly famous as "The Garden of Zealand", but for technical and economic reasons it was not considered desirable to restore the former natural bushes and trees. It is true that the 
numerous hawthorn hedges surrounding the fields used to afford a good protection against the salt sea winds, but the resultant loss of land was considered too great. But the view was held that a suitable system of hedgrows and trees should again be planted on Walcheren, and consequently a landscape project was drafted which not only took into account the favourable effect of windbreaks of trees and bushes on crop yields, but also the esthetic and recreational value of planting timber.

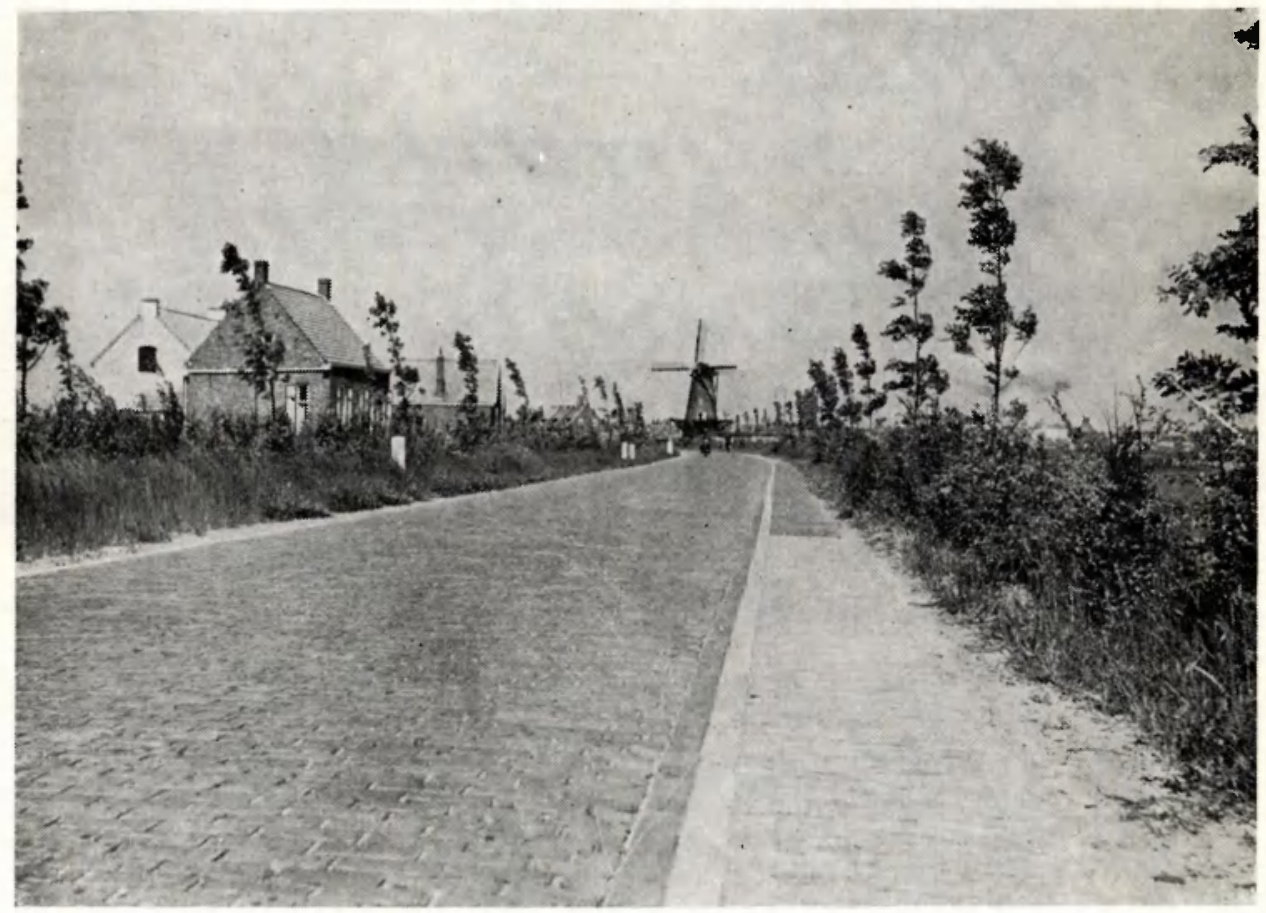

Fig. 5 The Walcheren taAndscape Will also be restored to its former beauty.

(Photo: Netherlands Land Development and Reclamation Society)

Woods were planted around a number of creeks on scoured land, as well as in the entire dune district from Westkapelle to Flushing. As a result the area afforested amounts to 160 hectares. Moreover 270 kilometres of roads and many farmyards were planted with trees and bushes. It is estimated that a total of 1 million trees and 2 million bushes were planted. Some 200 hectares were also laid out with fruit trees.

\section{ThE OPERATIONS}

During the initial period the work was chiefly done by manual labour, owing to the great number of unemployed labourers, both in the cities and on the island itself. Ditches were chiefly excavated by means of draglines and dumpers. Hundreds of hectares were levelled and drained with the spade. 2000 men a year ware employed in the winter and 600 in the summer. When the number of unemployed rapidly fell after 1952 the authorities cast about for other methods. During the beginning of the operations on some fields the 
soil was shifted by bulldozers, but is was soon found that this ruined the soil texture, especially owing to the soil being spread out and made impervious in layers. This method also resulted in the loss of too much topsoil. Subsequent experiments with draglines showed that these machines were very suitable for levelling work. During wet weather there was even more loss of texture from manual labour than from the use of draglines.

After 195050 draglines were in constant use on Walcheren, so that in 1952 it was not a difficult matter to switch over to entirely mechanical methods. In 1955 mechanisation was carried one step further with the use of pipe-laying trench diggers. The entire work was carried out by the Netherlands Land Development and Reclamation Society on a commission basis, or else by contactors under the management of the Society. By 1959 the operations were completed.

It will be clear that large sums of money were invested in the reclamation and agrarian reconstruction of the island. During the period from 1945 to 1946 the dykes were replaced by the Government Service of Waterways and Communications, and this alone costed $f 40$ millions. The first subsequent restoration works accounted for a further $f 15$ millions. The reallocation work began in 1948, the total cost being $f 80$ millions. This includes the cost of civil engineering operations for the purpose of water control and opening up $(f 30$ millions), land development operations, landscaping, construction of farmsteads and farm enlargement and compensations paid in connection with the operations. Finally the enlistment of unemployed labourers required a further amount of $f 15$ millions. Altogether an amount of $f 150$ millions was spent on the recon truction of the island of Walcheren.

Some part of this amount will be repaid to the State by the parties concerned over a period of 30 years. The payment is made on the basis of the increased value of their holdings. The increased value as compared to the situation before the flooding is specified in a second assesment drawn up in the years 1957 to 1959. On the basis of this assesment a list of financial settlements has been made and laid open to the inspection of the parties concerned.

\section{The RESUlts}

The great efforts and substantial investments made were fortunately not in vain. Owing to the new system of roads and watercourses and the rational form of parcelling it is now possible to farm the land in a more efficient way. The number of fields was reduced from 31,000 to 13,000 . Leaving out of consideration the 3,000 or more fields belonging to the built-up areas, a concentration of about $3: 1$ has been reached. In drafting the allocation plan everyone's wishes were taken into account as far as possible, the aim being to allocate land in such a way as to make it unnecessary to change over to a different type of farming.

Much was also achieved in the sphere of farm enlargement. For the first time in Holland it was found possible to help solve the problem of undersized holdings by farm enlargement. Before the war there were over 500 uneconomic smallholdings on Walcheren in the 3 to 10 hectare class. Under the land consolidation scheme the farmers were given the opportunity to lease a farm in the North-East Polder, and 118 of them seized this chance. As a result of their departure 1,534 hectares became available for reallocation. In the new polder 
the farmers were given 1,947 hectares of land; 75 obtained 12-hectare farms, 14: 18-hectare, 23: 24-hectare and 6: 36-hectare farms.

The land they left behind was used first of all for enlarging farms; 212 farms having a total area of 1,290 hectares were enlarged to 2,191 hectares, so that their average size increased from 6.2 to 10.3 hectares. In addition 29 market gardens were enlarged from 38 to 63 hectares, thereby increasing their average size from 1.3 to 2.2 hectares. The remaining area was used for making good lost land, afforestation, etc. The success of the farm enlargement project was jeopardised by the fact that the farms to be enlarged were not uniformly distributed over the areas in which land became available. In districts where the amount of land available was in excess of the requirements of neighbouring farms the problem was solved by building farms. In areas where insufficient land was available it was unfortunately impossible to assist every applicant. Despite the fact that an investigation into the labour effect showed that the average enlarged farm is too large for a one-man farm and too small for a two-man farm, the overall results were satisfactory and particularly valuable for the light they throw on farm enlargement problems in other areas

Generally speaking the Walcheren farmer has made good use of the entire improvement of the agrarian structure. Before the war there were 7,800 hectares of pastureland on the island; this area has now been reduced to 4,600 . Despite such a great extension of the arable area the total milk production has remained at practically the same level. This is to be explained by the improved quality and care of cattle, but above all to the betterment of the pastures and the grazing system. Moreover mechanisation has gained much ground owing to the larger size and compactness of the fields.

The good results outlined above are certainly also due to the work of the Agricultural Extension Service. It can be justly stated that there was' a properly directed extension on Walcheren. At first this direction was determined by the restoration of the soil. Advice was given regarding the selection of crops on salty soils, the calcium sulphate dressing needed and the seeding of grassland. Afterwards advisory pwork was needed on how to till the drained and levelled land, and specially in connection with farm enlargement or migration to the North-East Polder. Farmers were assisted in the exercise of their profession by means of mass and group information (circulars, discussion evenings, etc.) and by the giving of individual informatino (farm-visits). Regional soil surveys made it possible to give expert advice on land use. Numerous excursions to the specially established pilot farm have also had a favourable effect.

\section{ThE IMPORTANCE FOR LAND DEVELOPMENT IN GENERAL}

The experience gained in the agrarian reconstruction work of Walcheren is very important for the Government Service for Land and Water Use and for the Dutch land development works in general. Walcheren is the one area which has served to convince people that backward areas are best served by the most comprehensive possible approach in both the technical and the social and planning spheres.

The foundation has been laid for farm enlargement work in land consolidation projects. One factor that has emerged is the need for full co-operation of the population. Such concepts as initial and after-care have sprung up and 
been given a form and content. Moreover land forming, important for obtaining fields which can be worked by mechanical means, has been introduced on Walcheren. At the same time the mechanical execution of land development projects has also been stimulated by the experience gained on Walcheren. Finally, the reallocation project has also provided a good testing ground for research and planning.

But obviously the most important fact of all is that thanks to the reallocation project an out-of-date and dilapidated area is now able to stand beside modern and well-equipped farming districts. Both the Walcheren farmer and Dutch agriculture benefit as a result.

\section{REFERENCES}

1 Franke, Ir. A. : Cultuurtechnisch werk op Walcheren. Tijdschr. Ned. Heidemij 63, 11 (1952).

2 Herweijer, S., A. Franke and W. A. v. D. WERFF : Past and future of Walcheren. Food and Agriculture - The F.A.O. European Bulletin no. 4, 1949.

3 Jaarverslagen Cultuurtechnische Dienst 1956, 1957 en 1958.

4 KriJGer, R. : Landbouwvoorlichting in het herverkavelingsgebied Walcheren. Landbouwvoorlichting 13 (1956).

5 WERFF, Ir. W. A. VAN DER : De sanering van kleine bedrijven op Walcheren. Meded. Stichting voor de Landb. 8, 16 (1953).

6 - - : De herverkaveling Walcheren. Tijdschr. Ned. Heidemij 69, 4 (1958).

7 Zeeuws Landbouwblad, Walcheren-nummer 16 juni 1956. 